Scientił studia, São Paulo, v. 12, n. 1, p. $7^{3-95}, 2014$

\title{
त्री \\ O Trieb de Freud como instinto 1: sexualidade e reprodução
}

\author{
Richard Theisen Simanke
}

\begin{abstract}
范
RESUMO

O conceito freudiano de "impulso", ou "instinto" (Trieb), é reconhecidamente um dos conceitos mais fundamentais da psicanálise. No entanto, seu sentido ainda é objeto de controvérsia. Originalmente definido por Freud em um sentido biológico ou quase biológico, sua recepção em muitas das diversas tradições pós-freudianas tendeu, frequentemente, a recusar essa filiação epistemológica inicial. Um dos sinais dessa reorientação doutrinária é a recusa da tradução de "Trieb" por "instinto" e a preferência pelo neologismo "pulsão", de origem francesa e comum na literatura psicanalítica escrita em várias das línguas neolatinas, inclusive em português. O objetivo deste artigo é criticar essa tendência. Para tanto, são examinados os principais argumentos normalmente apresentados contra uma visão biológica do Trieb freudiano, a saber, 1) a alternativa terminológica entre os termos alemães "Trieb" e "Instinkt" e o modo como estes são utilizados por Freud; 2) a crítica freudiana de uma redução da sexualidade humana à função reprodutiva; 3) o conceito de "Todestrieb" ("instinto de morte" ou "pulsão de morte") formulado por Freud por volta de 1920 e central na etapa final de seu pensamento. Procura-se argumentar que essas formulações não impedem uma interpretação biológica do conceito de "Trieb". Essa interpretação, por sua vez, abre uma via de diálogo entre a psicanálise e a biologia, a qual é também enfática e explicitamente defendida por Freud. Esta primeira parte do trabalho introduz a questão e também aborda o problema da relação entre sexualidade e reprodução na psicanálise e na biologia. Uma segunda parte, a ser publicada em uma próxima edição de Scientiae Studia, será dedicada ao problema da agressividade e da autodestrutividade nessas duas áreas do conhecimento.
\end{abstract}

Palavras-chave • Freud. Psicanálise. Metapsicologia. Instinto. Pulsão. Biologia. Morte. Sexualidade.

\section{Por Que o Trieb NÃo SERIA INSTINTO?}

A discussão sobre o sentido do conceito freudiano de "Trieb" tem sido uma constante dentro da história da psicanálise. Freud não parecia ver grandes problemas em atribuir-lhe uma significação e uma fundamentação biológica. Sua primeira dualidade instintual era explicitamente baseada na distinção entre o conjunto de funções biológicas que servem à conservação da existência do indivíduo (para os instintos de autoconservação) e o conjunto de funções biológicas que servem à conservação da es- 
pécie (para os instintos sexuais) (cf. Freud, 1998 [1910]). ${ }^{1}$ Como se vê, a palavra-chave nessa primeira teoria freudiana dos instintos era "conservação". Freud parecia, nesse momento, entender o instinto como uma espécie de conatus orgânico, a saber, um esforço, inerente ao ser vivo, para continuar existindo, quer individualmente, quer como espécie. O conflito - inclusive no plano psíquico, isto é, no plano do funcionamento mental impulsionado pelas motivações instintivas - resultaria da impossibilidade de conciliar perfeitamente as metas dessas duas classes de instintos. Às vezes, a sobrevivência do indivíduo só poderia ser alcançada à custa do sacrifício da sobrevivência da espécie (basicamente, da renúncia àquelas atividades relacionadas com a reprodução) ou vice-versa.

Como se sabe, Freud (1998 [1920]; 1998 [1933]) revisou amplamente essa sua teoria inicial na virada dos anos 1920, introduzindo a célebre "segunda dualidade instintual" que opunha os instintos de vida (ou eros) aos instintos de morte (que outros autores, mas não Freud, designaram globalmente como tanathos). Uma das principais características dessa segunda dualidade era restringir o alcance quase universal que a primeira concedia à meta da conservação. Há várias razões para isso. Por exemplo, a teoria freudiana da sexualidade mostrara que as metas sexuais podiam divergir imensamente daquilo que tivesse a ver com a conservação da espécie, isto é, da função biológica da reprodução. Além disso, para dar outro exemplo, a agressividade era explicada pelo seu pertencimento ao grupo dos instintos de autoconservação, o que só conseguiria dar conta dos aspectos adaptativos da agressividade, mas não de suas formas patologicamente excessivas ou, muito menos, da agressividade autodirigida, a não ser mediante malabarismos teóricos pouco convincentes, tais como a postulação de um destino instintual de transformação no contrário (amor em ódio, tipicamente) ou de volta contra si mesmo (transformação de agressão alodirecionada em autodirecionada) ou, ainda, propondo a erotização dessa forma de agressão autodirecionada como masoquismo (cf. Freud, 1998 [1915]). Na nova teoria, por um lado, uma categoria - o eros ou os instintos de vida - passou a agrupar os instintos sexuais e de autoconservação da primeira dualidade, embora haja hesitações significativas de Freud em incluir a autoconservação nessa categoria. Na verdade, há, por vezes, até mesmo uma hesitação em subsumir integralmente a sexualidade na categoria dos instintos de vida (cf. Freud, 1998 [1923]). ${ }^{2}$ A meta geral dessa categoria de instintos foi definida como um impulso em direção a

\footnotetext{
1 Por uma questão de método, utilizei sistematicamente "instinto" para traduzir o Trieb freudiano ao longo deste trabalho, uma vez que um de seus objetivos é colocar em questão a heterogeneidade irredutível entre "instinto" e "pulsão", que é mais frequentemente assumida dentro do campo psicanalítico. Seja como for, traduções mais recentes de Freud em português fizeram também essa opção, como se menciona abaixo.

2 Para uma discussão das dificuldades encontradas por Freud em justificar a categoria dos instintos de vida (maior do que com relação ao instinto de morte, ao contrário do que muitos pensam), ver Caropreso \& Simanke (2008).
} 
uma maior complexidade e organização pela ligação de formas e estruturas mais simples, sejam elas orgânicas ou mentais. Por outro lado, Freud propôs a categoria dos instintos de morte que agiria na direção inversa, isto é, no sentido de desfazer as ligações estabelecidas, retornar a estados anteriores de menor complexidade estrutural e, no limite, à total ausência das formas de organização próprias dos seres vivos - em uma palavra, em um retorno ao estado inanimado da matéria (daí sua designação como instintos de morte).

Essa segunda dualidade apresenta diferenças significativas com relação à primeira. Em primeiro lugar, a meta geral da conservação encontra-se profundamente redefinida. Quando Freud fala do "caráter conservador dos instintos", ele não mais se refere a um esforço para conservar a existência do indivíduo ou da espécie, mas a uma tendência dos instintos a restaurarem um estado anterior da história da vida. Assim, quando discute o recém-introduzido conceito de compulsão à repetição, Freud afirma

mas, então, de que maneira o instintivo se relaciona com a compulsão à repetição? Aqui, só pode se impor a ideia de que estamos na pista de uma característica universal dos instintos (...) e, talvez, de toda a vida orgânica em geral. Um instinto seria, então, um esforço, inerente ao orgânico vivo, de reprodução de um estado anterior que o ser vivo teve que abandonar sob a influência de forças perturbadoras externas; ele seria um tipo de elasticidade orgânica ou, caso se preferir, a exteriorização da inércia na vida orgânica. Essa maneira de conceber o instinto pode soar estranha. De fato, habituamo-nos a ver no instinto o fator que impele no sentido da mudança e do desenvolvimento e agora vemo-nos obrigados a reconhecer no mesmo justamente o contrário, a expressão da natureza conservadora do ser vivo (Freud, 1998 [1920], p. 36).

O conceito de "instinto de morte" é, então, como que deduzido desse caráter conservador atribuído aos impulsos instintivos em geral.

Contradiria a natureza conservadora dos instintos o fato de que a meta da vida fosse um estado nunca alcançado antes. Este deve, antes, ser um estado antigo, inicial, que o ser vivo abandonou alguma vez e ao qual aspira regressar por todos os rodeios da evolução. Se for legítimo admitir como uma experiência sem exceções que todo ser vivo morre, regressa ao inorgânico por razões internas, não podemos dizer nada de diferente disso: a meta de toda vida é a morte. E, retrospectivamente: o inanimado esteve aí antes do que é vivo (Freud, 1998 [1920], p. 38). 
Trata-se agora de um conservadorismo retrógrado, por assim dizer. Este revelou-se uma propriedade difícil de atribuir aos instintos de vida. Freud procurou estabelecer, de diversas maneiras, qual poderia ter sido o estado anterior a que esses instintos almejavam retornar (um estado de fusão e indiferenciação originária entre os organismos, por exemplo), mas, ao fim e ao cabo, renunciou a essas tentativas e reservou a meta do retorno a um estado anterior apenas aos instintos de morte. ${ }^{3}$ De fato, essa tese aplicava-se perfeitamente a estes últimos, mediante a consideração de que a existência da matéria inanimada evidentemente precedeu o surgimento da vida e foi condição para o mesmo.

Uma segunda e importante diferença é que essa segunda dualidade ampliava o sentido do conceito de instinto tal como este se apresentava na primeira teoria. Antes o instinto era definido como o representante psíquico de processos somáticos contínuos e incoercíveis, ou como o ponto de articulação entre o psíquico e o somático ou, ainda, como uma medida da exigência de trabalho imposta à mente em função de sua ligação com o corpo (cf. Freud, 1998 [1905]; 1998 [1915]). Em todas essas definições, a noção de instinto parecia se aplicar somente aos processos mentais em sua relação com o corpo ou, dito de outra maneira, aplicava-se aos processos corporais apenas na medida em que estes interessassem à estrutura e ao funcionamento da mente. Nesse sentido, "instinto", na primeira teoria, é um conceito estritamente psicológico ou, mais precisamente, metapsicológico, um operador teórico da articulação entre o psíquico e o somático. Na segunda teoria, Freud não hesitou em definir o instinto como um esforço inerente ao orgânico para atingir determinadas metas (o retorno a um estado anterior e, no limite, ao estado inanimado, por exemplo). O conceito de "instinto" adquire, assim, uma significação abertamente biológica, e sua expressão psicológica aparece como derivada de sua natureza biológica fundamental e como um caso particular de sua manifestação.

Nada há de surpreendente, portanto, em que Freud (cf. 1998 [1920] e outros textos posteriores) tenha recorrido ainda mais intensamente a considerações de ordem biológica - ainda que fortemente especulativas - no tratamento dos problemas envolvidos na teorização sobre os instintos e sobre sua participação na vida mental. Ele afirmou claramente que a fundamentação da teoria só poderia ser biológica e que a psicanálise não poderia, por si só, alcançar uma definição de instinto plenamente satisfatória. É notável como, nesse período final de sua produção teórica, Freud tenha tornado a enfatizar o elemento constitucional na determinação dos processos mentais normais e patológicos e, consequentemente, privilegiado os fatores filogenéticos, for-

3 Uma discussão mais completa das idas e vindas e das nuanças da formulação da segunda dualidade instintual freudiana pode ser encontrada em Caropreso (2010a). Veja-se, sobretudo, o capítulo 4 . 
mados ao longo da história evolutiva da espécie, em detrimento dos fatores ontogenéticos, referentes à história de vida dos indivíduos. Com isso, considerações de ordem biológica vêm mais ou menos naturalmente para o primeiro plano. Assim, por exemplo, ao refletir sobre as causas da angústia e das neuroses, ele afirma que

\begin{abstract}
as considerações que fizemos mostram-nos que são as relações quantitativas, não passíveis de serem investigadas de forma direta, mas apenas por meio da inferência retrospectiva, aquelas que decidem se as antigas situações de perigo serão retidas, se as repressões do eu serão conservadas, se as neuroses da infância terão ou não continuação. Entre os fatores que participaram da causação das neuroses, que criaram as condições sob as quais se batem entre si as forças psíquicas, há três que ganham destaque para nosso entendimento: um biológico, um filogenético e um puramente psicológico (Freud, 1998 [1926], p. 145, grifos meus).
\end{abstract}

Dos três fatores explicativos mencionados, o fator biológico é identificado como a prematuração do recém-nascido e seu consequente desamparo (um tema familiar à biologia da evolução humana e à antropologia biológica; cf. Gould, 1977). O fator aqui identificado como filogenético - no sentido de que relaciona o desenvolvimento individual (ontogênese) à história evolutiva da espécie - é definido como o desenvolvimento em dois tempos da sexualidade humana, com seu período infantil e adulto separados por um período de relativo declínio da intensidade do impulso sexual, chamado de fase de latência. Mas mesmo o fator considerado como psicológico - a saber, a diferenciação do eu a partir de um id instintivo originário - está longe de ser independente de determinações biológicas e evolutivas. Veja-se, por exemplo, o tipo de considerações que Freud elabora quando discute a relação entre a herança filogenética do id e a formação do ideal do eu.

O que a biologia e os destinos da espécie humana realizaram no id e lhe deixaram como sequela é o que o eu assume através da formação do ideal e o que é revivido nele individualmente. $\mathrm{O}$ ideal do eu, como consequência de sua história de formação, tem as maiores relações com as aquisições filogenéticas, essa herança arcaica do indivíduo (Freud, 1998 [1923], p. 38).

Tudo isso poderia levar a crer que o termo "instinto", no entrecruzamento de sua significação biológica e metapsicológica, se encontrasse perfeitamente bem empregado aqui em uma acepção próxima da que costuma ter nas teorias oriundas do campo da biologia do comportamento. Contudo, sabemos que boa parte das tradições pósfreudianas não chegou a esse tipo de conclusão. Nelas encontramos frequentemente 
uma recusa em admitir a significação biológica que Freud tão claramente atribuiu ao seu conceito de "instinto". Essa recusa manifestou-se em um esforço de refundamentação da teoria freudiana em outras bases (antropológicas ou linguísticas, como aconteceu, por exemplo, com a psicanálise lacaniana). No plano da tradução, essa atitude resultou, entre outras coisas, na rejeição total do vocabulário biológico - do qual o termo "instinto" evidentemente faz parte - e na invenção de um neologismo para substituí-lo, a saber, o francês "pulsion", que se difundiu então para outras línguas neolatinas ("pulsión” em espanhol, "pulsão" em português etc.). Autores como Lacan e Laplanche são emblemáticos dessa tendência voltada para uma radical desnaturalização do Trieb freudiano, tanto no plano teórico como terminológico. Cabe esclarecer que por "desnaturalização" designa-se aqui especificamente o esforço de afastar a psicanálise freudiana de uma fundamentação biológica. Consequentemente, sempre que se falar, na continuidade, de uma "naturalização" dos conceitos psicanalíticos, o termo se referirá a uma crítica das interpretações que produzem desnaturalização nesse sentido restrito e à defesa da viabilidade - assim como do interesse filosófico e científico - de uma reaproximação entre a psicanálise e as ciências biológicas. Evidentemente, esse não é o único sentido possível do termo, que pode, em princípio, referir-se a uma definição ou fundamentação dos conceitos psicanalíticos nos termos de qualquer disciplina do campo das ciências humanas (antropologia, sociologia, linguística etc.) desde que entendida na perspectiva de uma epistemologia naturalista, ou seja, desde que se recuse a ruptura epistêmica entre as ciências humanas e as ciências da natureza e/ou a fratura ontológica entre seus respectivos domínios de objeto. Esse sentido mais restrito de naturalização foi adotado devido ao fato de que as interpretações a cuja crítica se procede aqui, quando propõem uma refundamentação da psicanálise em termos antropológicos ou linguísticos, por exemplo, invariavelmente assumem essas disciplinas em suas versões estritamente antinaturalistas (estruturalistas, sobretudo, no caso de Lacan e Laplanche). Seja como for, no que se refere a Freud, não se trata tanto de "naturalizar" os conceitos psicanalíticos, mas de resgatar sua significação naturalista originária, rejeitada por sua recepção posterior. Há inúmeras evidências de que Freud sustentava uma visão naturalista das ciências sociais. Mencionemos apenas uma, em que ele afirma a continuidade entre evolução biológica e cultural.

Logo chegará o tempo em que se poderá ampliar uma tese que nós, psicanalistas, formulamos há muito tempo, acrescentando a seu conteúdo, que é válido para o indivíduo entendido ontogeneticamente, o complemento antropológico, de concepção filogenética. Temos afirmado: "no sonho e na neurose reencontramos a criança, com as propriedades de seu modo de pensar e de sua vida afetiva”. Com- 
pletaremos: "também encontramos o homem selvagem, primitivo, tal como ele se mostra à luz da arqueologia e da etnologia" (Freud, 1998 [1911], p. 76).

Seja como for, onde a influência de autores como Lacan e Laplanche se fez sentir mais intensamente, o uso do termo "pulsão" tornou-se tão disseminado que sua tradução por "instinto" - na edição standard inglesa e na brasileira, traduzida a partir daquela, por exemplo - passou a soar como bizarra e anacrônica e a ser entendida como o resultado de um erro básico de tradução e de interpretação conceitual. Contudo, das duas traduções mais recentes e ainda em curso no Brasil, que, apesar de suas diferenças, são ambas projetos imensamente mais rigorosos e responsáveis que o anterior, pelo menos uma tornou a optar por traduzir "Trieb" por "instinto". Trata-se da tradução realizada por Paulo César Souza, publicada pela Companhia das Letras (a outra tradução estava sendo coordenada por Luiz Alberto Hanns e sendo publicada pela Editora Imago). Esta é uma opção decorrente de uma interpretação conceitual, e não apenas terminológica. Por exemplo, em uma entrevista, Souza afirmou que

\begin{abstract}
(...) "pulsão" (sic) me parece um neologismo feio e duvidoso. Acho significativo que venha da psicanálise francesa, de uma tradição dualista e cartesiana do pensamento, pois tem um viés espiritualizante: animais têm instintos, afirma-se, enquanto os humanos têm pulsões. Acredito mais em um amigo que disse o seguinte, quando lhe perguntei o que achava: "Pulsão têm os anjos, meu querido; gente tem instinto" (Savian Filho, 2010, p. 58).
\end{abstract}

Ao mesmo tempo, a questão da proximidade entre a psicanálise e as ciências naturais e biológicas retorna com força na atualidade, na esteira de alguns desenvolvimentos internos à psicanálise, mas, sobretudo, do desenvolvimento científico em áreas vizinhas como a neurobiologia e a biologia evolucionária, por exemplo. Talvez valha a pena, então, recolocar em discussão a posição segundo a qual o Trieb freudiano nada teria que ver com o conceito biológico de "instinto". Trata-se de um caso claro do que se costuma chamar de visão consolidada, isto é, uma concepção aceita sem grandes questionamentos, pelo peso da tradição, por hábito ou por certa inércia do pensamento. O que haveria, afinal, de tão impensável nessa aproximação?

Examinemos três argumentos típicos contra a mesma - uma objeção linguística e duas objeções conceituais. Sinteticamente, esses argumentos afirmam o seguinte:

(1) Freud teria empregado diferencialmente os termos germânicos "Instinkt" e "Trieb", utilizando claramente o primeiro para se referir ao comportamento animal e o segundo, exclusivamente, para os fenômenos 
humanos (cf. Mills, 2004; Tavares, 2013; Laplanche, Cotet \& Bourguignon, 1989). Logo, Instinkt e Trieb seriam coisas completamente diferentes e deveríamos referir-nos a eles como "instinto" e "pulsão" respectivamente. (2) Freud (a partir de 1998 [1905]) teria empreendido uma radical desnaturalização da sexualidade humana (cf. Hoffmann, 2007, 2010; Laplanche, 1970), desvinculando-a de sua finalidade biológica reprodutiva e mostrando que ela pode ser definida por metas distintas do coito heterossexual, e visar objetos indefinidamente divergentes daquele biologicamente adequado à reprodução (isto é, outro ser humano, do sexo oposto, adulto, fértil etc.). Ora, o instinto sexual dos animais teria por meta a reprodução. Logo, o Trieb sexual humano teria que ser algo totalmente diferente de um instinto.

(3) Freud teria proposto a ideia de um "Todestrieb", um impulso interno voltado para a autoaniquilação e para o retorno ao inanimado. Tal ideia careceria totalmente de uma significação biológica e seria impensável desde esse ponto de vista (cf. Laplanche, 1970). Se fosse para ela ser mantida como um conceito central da psicanálise - como parece ter sido o caso para Freud - o "Trieb", nesse substantivo composto, teria que ser algo inteiramente distinto do "instinto" tal como a biologia utiliza esse conceito.

Às duas últimas objeções se acrescenta, às vezes, a consideração de que a biologia contemporânea encontra-se, em grande medida, organizada em torno do paradigma evolucionário darwinista (ou neodarwinista). Segundo esse paradigma, as características morfológicas, fisiológicas e comportamentais se explicariam pela acumulação de variações favorecidas pela seleção natural devido a sua capacidade de propiciarem maior sucesso reprodutivo diferencial aos organismos que as possuíssem. Como, portanto, coisas como uma sexualidade sem reprodução ou um instinto de morte poderiam ser favorecidas pela seleção natural, já que consistem em características evidentemente desadaptativas?

O objetivo da discussão que se segue é verificar em que medida é possível responder a essas objeções.

\section{O uso do termo “Trieb” na Biologia}

A objeção linguística parece a mais fácil de ser afastada. O termo "Trieb" tem sido de uso corrente na biologia de língua germânica desde tempos anteriores a Freud, onde foi empregado para significar o que é usualmente designado como "instinto" na lite- 
ratura biológica. De fato, os dois termos são, nesse contexto, às vezes, empregados de forma perfeitamente intercambiável. O campo semântico de "Trieb", é claro, é muito mais amplo que o de "Instinkt" e, na verdade, o inclui. Assim, entre os significados principais de "Trieb" incluem-se "instinto, força inata de origem biológica, dirigida a certas finalidades" (Hanns, 1996, p. 339). Em diversos momentos de sua análise, essa possibilidade é reconhecida, como, por exemplo, ao comentar os sentidos de "Trieb" no Vocabulário da língua alemã (Deutsches Wörterbuch) dos irmãos Grimm, quando reporta que "na filosofia e na psicologia do século xviı tem o sentido de "Instinkt" e designa as emoções (Regungen) primitivas e naturais" (Hanns, 1996, p. 3411). Ou, ainda,

[os "Triebe"] podem referir-se (...) à manifestação biológica dessas forças universais nas espécies: as poderosas forças biológicas básicas (o "instinto" de mamar, o gregarismo etc.). Ainda dentro da esfera biológica, o termo serve para designar pulsões biológicas específicas (Hanns, 1996, p. 350).

O próprio Laplanche - um dos principais protagonistas da desnaturalização da teoria freudiana dos instintos e defensor da sua tradução como "pulsion" - reconheceu que "certos autores parecem empregar indiferentemente os termos 'Instinkt' e 'Trieb" (Laplanche \& Pontalis, 1995, p. 394). Os autores dão como exemplo o livro, A noção de instinto ontem e hoje (...), "onde Ziegler fala umas vezes de 'Geschlechtstrieb' e outras de 'Geschlechtsinstinkt'" (Laplanche \& Pontalis, 1995, p. 396).

Freud mesmo esteve longe de manter escrupulosamente essa distinção e utiliza o termo Instinkt também para referir-se aos impulsos humanos. Assim, diz ele que “Trotter inclui na relação de impulsos (Triebe) ou instintos (Instinkte), que considera primários, os de autopreservação, nutrição, sexo e gregário (Selbstbehauptungs-, Ernährungs-, Geschlechts- und Herdentrieb)" (Freud, 1998 [1921], p. 112). Na mesma entrevista mencionada acima, Souza comenta, a esse respeito,

sim, ele [Freud] usa essa palavra ["Instinkt"] umas poucas vezes, mas não faz essa distinção clara que alguns afirmam. Em alemão, "Instinkt" foi adotado no século xviır, como parte da linguagem culta, enquanto o termo germânico tradicional, "Trieb", continuou sendo mais usado. Os campos semânticos de um e de outro se superpõem em parte, por isso a frase inicial dos Três ensaios de uma teoria da sexualidade, por exemplo, usa "Trieb" como referência ao instinto sexual tanto dos seres humanos quanto dos animais, e Freud prossegue lembrando a analogia com o "Trieb da alimentação", a fome, ao qual corresponde a "libido" no âmbito sexual (Savian Filho, 2010, p. 58). 
Por outro lado, Freud manifestou claramente sua posição de não separar taxativamente os fenômenos humanos do comportamento animal, ao contrário do que seria de se esperar se aplicasse consistentemente Trieb para os primeiros e Instinkt para os últimos. Assim, em um texto inteiramente dedicado à interpretação da cultura uma especulação histórica sobre as origens do judaísmo -, pode-se ler que:

reduzimos o abismo excessivo que o orgulho humano de épocas anteriores abriu entre o homem e os animais. Se os chamados "instintos" (Instinkte) dos animais, que lhes permitem comportarem-se desde o começo em uma nova situação vital como se fosse antiga, se a vida instintiva dos animais admite uma explicação, esta só pode ser que eles trazem como congênitas, para sua nova existência própria, as experiências de sua espécie (...). E, no animal humano, as coisas não seriam no fundo diferentes. Sua própria herança arcaica corresponderia aos instintos (Instinkte) dos animais, ainda que seu alcance e conteúdos fossem diversos (Freud, $199^{8}$ [1938], p. 96-7, grifos meus).

Embora Freud tenha, de fato, nessa passagem, utilizado o termo "Instinkt" para referir-se aos aspectos hereditários do comportamento animal, ele também afirma que os componentes inatos da ação humana (supostamente, os Triebe, das Es etc.) não são essencialmente distintos. Daí a concluir que o Trieb freudiano designe a forma específica pela qual o comportamento instintivo manifesta-se nos seres humanos não parece ser um passo excessivamente temerário.

É significativo como Konrad Lorenz (1975 [1937]) - um dos fundadores da moderna biologia do comportamento e um dos principais teóricos do comportamento instintivo - tenha praticamente se desculpado por empregar o termo "Instinkt" em vez de "Trieb" (que, a seu ver, seria mais apropriado), devido ao fato de que este último se tornara, por assim dizer, propriedade intelectual de escolas psicológicas - incluindo a psicanálise e o behaviorismo - que tendiam a negar, em sua interpretação, a existência de um componente inato no comportamento (Lorenz provavelmente tem em vista aqui a teoria dos impulsos (drive theory) de Clark Hull). As passagens abaixo deixam claro o quanto o termo "Trieb" pode ser apropriado a uma explicação biológica do comportamento.

Quero acrescentar uma palavra sobre a terminologia usual. "Instinto" é apenas uma palavra abstrata. A única coisa sobre a qual podemos pronunciar-nos é o ato instintivo (...). Heinroth, para evitar a ambiguidade da palavra "instinto", empregou a expressão "ato específico da pulsão" ("arteigene Triebhandlung”) em lugar de 'ato instintivo' ("Instinkthandlung"), o que é sem dúvida a melhor designação. O que me incita a insistir na expressão "ato instintivo" é o fato da palavra 
"pulsão" ("Trieb") ou o termo inglês "drive" terem sido recentemente introduzidos em meios onde se desenha precisamente a tendência para negar a existência do que entendemos por essa palavra. Para evitar qualquer confusão com os conceitos de "pulsão" (...) dos behavioristas americanos e com o dos psicanalistas, abandonei a palavra alemã para usar o termo latino (Lorenz, 1975 [1937], p. 10).

Parece possível concluir que o argumento linguístico, por si só, seja insuficiente para uma separação total entre o conceito biológico de instinto e o Trieb freudiano. O termo "Trieb" é de uso corrente na biologia e sequer é o caso que Freud tenha feito, por sua própria conta, uma distinção tão taxativa entre as duas noções, pelo menos não no sentido de propor uma determinação para a ação humana que seja totalmente heterogênea com relação à explicação do comportamento animal. Isso não significa, evidentemente, que o termo "Trieb" tenha necessariamente uma significação biológica ou, sequer, que seja a principal significação ou a significação mais frequente e comum do vocábulo. De fato, no seu sentido mais geral de "impulso", o termo aparece no vocabulário de diversas outras correntes filosóficas ou científicas que também tiveram influência sobre Freud (Nietzsche, o pensamento romântico etc.). Basta, para os propósitos aqui em vista, evidenciar que o termo pode ter uma significação biológica, que essa significação, quando presente, tem afinidades com o que a biologia chama de "instinto" e que o termo foi, de fato, concretamente utilizado dessa maneira, mesmo que deixemos de lado, por ora, de que tipo de biologia se trata. ${ }^{4} \mathrm{Ou}$ seja, não é verdade que, como frequentemente se argumenta dentro do campo psicanalítico, caso Freud tivesse desejado atribuir uma significação biológica a seu conceito, ele teria tido que empregar, forçosamente, a denominação alternativa "Instinkt".

\section{O Trieb SEXUAL como instinto}

Com relação ao instinto sexual, a distância entre Freud e as concepções biológicas pode parecer evidente. Afinal, Freud (1998 [1905]) mostrou que a sexualidade humana podia divergir indefinidamente da meta biológica da reprodução. O que se observa nos Três ensaios é, de fato, uma ampla redefinição da sexualidade. Freud partiu de uma crítica extremamente minuciosa de certo conceito de sexualidade que a vincularia exclusivamente àquelas ações que estivessem diretamente relacionadas, de alguma maneira, à reprodução humana e, no limite, somente ao coito heterossexual. Essa definição es-

4 Não é necessário entrar no mérito dessa questão, porque as posições criticadas aqui se caracterizam, muito tipicamente, por recusar ao termo e ao conceito de Trieb uma significação biológica enquanto tal, seja ela qual for. 
taria, supostamente, amparada em bases biológicas. Ele demonstrou, de modo extremamente convincente, que este é um conceito excessivamente restrito de sexualidade, incapaz de incluir, em sua extensão, uma imensa gama de comportamentos que os próprios autores que utilizam esse conceito consideram como sexual, antes de tudo, as assim chamadas perversões ou aberrações (Abirrungen) sexuais. De fato, se existe um denominador comum para toda a variedade de manifestações do que o século xix considerava como patologias sexuais, é que nenhuma dessas formas de organização da vida sexual (inversões, fetichismo, sadomasoquismo etc.) permite o cumprimento da meta reprodutiva. Por que então chamá-las de sexuais - como se perguntou Freud - se a sexualidade estaria, por definição, restrita à reprodução? O que Freud detectou aqui, primeiramente, foi uma incongruência interna entre a intensão e a extensão do conceito de sexualidade, tal como empregado pela ciência e pela medicina de sua época. Um argumento complementar era fornecido pelas práticas do prazer preliminar (ou pré-prazer, Vorlust), que evidenciavam como nem mesmo a mais "normal" e conservadora vida sexual podia consistir exclusivamente no coito (ou teríamos que, por uma espécie de reductio ad absurdum, admitir que um beijo ou uma carícia nada tivessem que ver com a sexualidade). Na verdade, pode-se dizer que o argumento freudiano sustentava, em última instância, que reduzir a vida sexual à reprodução seria algo mais grave do que formular uma definição ruim ou limitada da sexualidade. No limite, sua crítica pode ser reconstruída de forma tal a apontar que essa extrema insuficiência do conceito sugeriria que essa redução sequer fosse uma definição no sentido estrito da palavra. Tratar-se-ia, antes, de uma norma sexual travestida de definição, uma prescrição daquilo que seria aceitável como conduta sexual em certo contexto sócio-histórico, e não uma descrição daquilo em que a sexualidade consiste. A crítica desenvolvida por Freud no primeiro dos Três ensaios pode, assim, ser entendida como um esforço para separar, no tratamento da sexualidade, as questões de fato (o que a sexualidade é) das questões normativas que se imiscuem em sua investigação (o que a sexualidade pode ou deve ser). Uma evidência disto é que o único argumento da psicopatologia da época para considerar as perversões como sexuais, muito embora elas se afastem por definição da meta reprodutiva, é que estaríamos aí diante de formas anormais da sexualidade (em geral, constitucionalmente anormais: taras hereditárias, degenerações etc.).5

5 Apesar do rigor da sua crítica, podemos duvidar de que Freud tenha obtido pleno êxito em expurgar completamente sua concepção da sexualidade de considerações de ordem normativa. Embora tenha demolido peça por peça a norma reprodutiva, ele tende, na análise diferencial da sexualidade feminina e masculina, a tomar a segunda como um parâmetro para a consideração da primeira. Ao tratar da sexualidade feminina, Freud claramente hesita entre um discurso sobre a diferença e um discurso sobre a falta. Na medida em que este último predomine, ele estaria assumindo a sexualidade masculina como norma para a abordagem da feminina, de tal maneira que uma mulher seria sempre um homem menos alguma coisa (o falo, em todas as suas dimensões, simbólicas, imaginárias etc.). A universalização desse discurso sobre a falta na psicanálise lacaniana tendeu a agravar esse problema, que Lacan tentou 
Nas entrelinhas de sua crítica, Freud foi elaborando um conceito utilizável de sexualidade, uma verdadeira definição, capaz de cobrir a totalidade das manifestações daquilo que ordinariamente se considera como sendo de natureza sexual. $\mathrm{O}$ exame das perversões mostrou-lhe que a restrição da meta sexual ao coito e do objeto à escolha heterossexual era extremamente insuficiente. O exame dos pares sadismo/masoquismo e voyeurismo/exibicionismo evidenciara como a meta podia divergir do coito (infligir ou sofrer dor, ver ou ser visto etc.). O exame da homossexualidade, da zoofilia, da pedofilia etc. - mas, sobretudo, do fetichismo - mostrara, por sua vez, que praticamente qualquer coisa poderia servir como objeto da sexualidade. Ora, dizer que a sexualidade pode ter virtualmente qualquer objeto é o mesmo que dizer que ela não possui nenhum objeto em especial, ou que não é possível defini-la pelo lado do objeto. Daí que Freud concluísse que a sexualidade fosse primordialmente autoerótica e que o problema da escolha do objeto apenas se colocasse secundariamente no processo de seu desenvolvimento. Restava-lhe tentar definir a sexualidade pela meta. Nesse caso, o único denominador comum para as diversas práticas sexuais seria encontrado na busca do prazer como um fim em si mesmo, isto é, desvinculado da reprodução ou de qualquer outra finalidade orgânica. Seria sexual todo prazer corporal visado por si só, sem atenção às funções biológicas desempenhadas pelas partes do corpo envolvidas; o prazer oral, sem referência à alimentação, o prazer anal, sem referência às necessidades da excreção, o prazer genital, independentemente da reprodução, e assim por diante. Evidentemente, essa definição da sexualidade centrada na meta do prazer corporal desvinculado de suas demais funções biológicas não a restringe a nenhuma região corporal específica. Consistentemente, Freud afirmou que a erogeneidade potencial é uma propriedade comum a todas as regiões corporais. Freud depois empregou o conceito de "apoio" ("Anlehnung”), juntamente com o de narcisismo, para tentar resolver o enigma de como essa sexualidade originariamente anobjetal chegava afinal a encontrar um objeto. Esse conceito, contudo, possui uma significação eminentemente negativa. A sexualidade, de fato, só surgiria quando o apoio cessasse (quando o prazer oral se tornasse independente da alimentação e passasse a ser buscado como um fim em si mesmo, o mesmo valendo para o prazer anal, e assim por diante).

Todos esses desenvolvimentos parecem apontar para uma desvinculação entre a sexualidade humana e sua finalidade biológica e sugerir uma ampla desnaturalização da mesma. Por isso, para os defensores de uma teoria psicanalítica menos biológica, seria necessário falar de uma pulsão (Trieb) sexual, no caso humano, qualitativamente

solucionar quer dissolvendo a diferença entre questões normativas e questões de fato (ao propor, por exemplo, uma "ética do real"; cf. Lacan, 1986 [1959-1960]), quer atribuindo à mulher a possibilidade de um gozo não fálico e, com isso, a possibilidade de uma feminilidade não histérica (cf. Lacan, 1999 [1972-1973]). Esse tema é desenvolvido mais longamente em Simanke (2013). 
distinta e praticamente em oposição ao instinto (Instinkt) sexual das demais espécies animais. Mas isso só seria verdade se essas características distintivas - independência da reprodução e uma meta definida como um prazer não utilitário - fossem mesmo exclusivas da espécie humana. No entanto, considerando a questão do ponto de vista da biologia, é possível verificar que a independência relativa da reprodução está longe de ser exclusiva, e que a função do prazer está longe de ser desprovida de uma significação biológica.

O primeiro ponto pode ser ilustrado recorrendo-se às considerações sobre a sexualidade de Edward O. Wilson (1978), criador da sociobiologia e, certamente, um dos mais ardentes (e polêmicos) defensores, nas últimas décadas, de uma visão biológica da ação humana. Na abertura do capítulo sobre o comportamento sexual, com efeito, pode-se ler que:

o sexo é central para a biologia humana, é um fenômeno multiforme que permeia todos os aspectos de nossa existência e assume novas formas a cada passo no ciclo da vida. Sua complexidade e ambiguidade são devidas ao fato de que o sexo não está projetado originariamente para a reprodução. A evolução inventou, para as criaturas multiplicarem-se, meios muito mais eficientes que os complicados procedimentos de acasalamento e fecundação (...). Se a multiplicação fosse o único propósito do comportamento reprodutivo, nossos ancestrais da classe dos mamíferos poderiam ter evoluído sem o sexo. Cada um dos seres humanos poderia ser assexuado e germinar nova descendência a partir das células superficiais de um útero tornado neutro (neutered) (Wilson, 1978, p. 121, grifos meus).

Em princípio, portanto, não há impedimento para que a reprodução mamífera e humana ocorresse assexuadamente, de forma neutra quanto ao gênero, ou seja, independentemente da separação dos indivíduos em dois ou mais sexos. Assim, mesmo de um ponto de vista estritamente biológico, a sexualidade não teria na reprodução sua meta principal, e sua relação com a perpetuação das espécies não explicaria integralmente seu surgimento no curso da evolução. Consequentemente, desvincular sexo e reprodução não é, por si só, razão para abandonar uma visão biológica da sexualidade. Se o conceito de "instinto" representa o conjunto dos determinantes biológicos do comportamento - aquilo que cada indivíduo herda da sucessão de gerações que constituiu a evolução de sua linhagem (sua filogênese, termo que Freud não hesita em empregar, aliás, frequentemente) - não haveria razão para deixar de falar de um instinto sexual humano e de atribuir essa significação ao Trieb sexual de que fala Freud. É claro que o comportamento sexual humano apresenta algumas características que lhe são próprias, mas, em primeiro lugar, isso pode ser afirmado de qualquer outra espécie. 
Cada espécie é, em certo sentido, única, e é isso que faz de uma dada população de organismos uma espécie e não parte de alguma outra. ${ }^{\mathbf{6}}$ Em segundo lugar, essas características distintivas não deixam de ser de natureza biológica ou de estarem relacionada com as características biológicas específicas da espécie humana, a saber, a disseminação da receptividade sexual ao longo de todo o ciclo menstrual da mulher, a ocultação da ovulação, a longa dependência dos cuidados parentais, o retardo da puberdade e do amadurecimento sexual, a intensificação do convívio social etc.

A própria teoria psicanalítica do complexo de Édipo, por exemplo, poderia ser pensada como o modo freudiano de descrever como os efeitos de certas condições biológicas do desenvolvimento humano atuam na determinação da escolha de parceiros. O tema freudiano da "escolha de objeto" é amplamente estudado na biologia sob a forma do problema da escolha de parceiros (mating). Essas condições incluiriam a prematuração ao nascer e o desamparo originário do recém-nascido, que foram apontados por Freud, na parte final de sua obra, como os fatores biológicos em ação na determinação da angústia e das diversas patologias (Caropreso, 2010b). Isso e mais a lentidão do desenvolvimento, o retardo do amadurecimento sexual e a consequente dependência prolongada dos pais interferem decisivamente na solução do problema fundamental da escolha dos parceiros sexuais no caso específico da espécie humana (cf. Diamond, 2006 [1993], cap. 5). A dependência prolongada exige a formação de vínculos intensos entre pais e filhos, e poucos vínculos são mais intensos do que aqueles criados pela atração sexual. Por outro lado, se pensarmos que a evolução depende da propagação de certos conjuntos de genes, a seleção natural deveria favorecer o acasalamento com parentes próximos, com os quais os parceiros potenciais possuem mais semelhança genética e, com isso, maior probabilidade de ter os seus genes representados na prole e nas gerações posteriores. O limite para essa estratégia é o aumento da probabilidade de danos genéticos decorrentes de alelos que, na sua forma híbrida podem ser benéficos ou neutros, mas na forma dupla recessiva são prejudiciais ou letais. Isso porque o acasalamento com parceiros geneticamente semelhantes aumenta a probabilidade de

60 que está em questão nessa discussão é, em última instância, o problema antropológico da singularidade humana. Mas a resposta ao problema da singularidade não precisa ser inevitavelmente antinaturalista. Foley (1987) aborda a especificidade humana de um ponto de vista ambiental e evolucionário e fala do homem como "apenas mais uma espécie única". Schaeffer (2007) desenvolve exaustivamente esse argumento ao defender o "fim da exceção humana”. Desde o final dos anos 1970, a assim chamada sociologia ambiental norte-americana defende uma visão naturalista das ciências sociais, tendo cunhado o termo "isencionalismo" (exemptionalism) para criticar as visões antinaturalistas que pensam o comportamento humano como isento das determinações ordinárias no mundo natural (cf. Catton \& Dunlap, 1978). Essa é uma discussão mais ampla que atravessa o problema mais restrito em foco aqui, a saber, até que ponto é possível interpretar o conceito de"Trieb" freudiano como "instinto", no sentido biológico do conceito, o que resultaria em dissolver a especificidade ontológica absoluta do ser e da ação humana que a noção de "pulsão" parece conotar. 
a forma dupla recessiva ocorrer. Haveria assim uma tensão entre uma tendência a acasalar com parentes próximos e geneticamente semelhantes e a tendência a evitar uma proximidade excessiva, que viria a ser prejudicial. A atração incestuosa e os mecanismos que a inibem seriam, assim, expressão psicológica dessas tendências biológicas conflitantes, e instituições sociais como a exogamia e os tabus do incesto seriam agenciamentos culturais para a administração dessas tendências. A teoria freudiana do Édipo poderia ser interpretada, então, como a análise das consequências psíquicas desse sistema de tendências biológicas que se traduzem em instituições culturais. Mas não seria contraditória com a maneira como a biologia vê o processo de escolha dos parceiros sexuais, de modo geral e não apenas na espécie humana.

Mas para que serve então a sexualidade, se não apenas para a reprodução? Qual a sua função biológica originária, se esta não é a multiplicação dos indivíduos? A primeira resposta a essa pergunta, sempre de um ponto de vista estritamente biológico, é que a reprodução sexuada produz diversidade genética, isto é, dá origem a populações mais geneticamente heterogêneas do que a reprodução assexuada. A diversidade genética, por sua vez, é um evidente fator de propiciação da sobrevivência da prole.

Portanto, há boas razões para a reprodução não ser sexuada; ela pode ser individual, direta, segura, energeticamente barata e egoísta. Por que, então, o sexo evoluiu? A resposta principal é que o sexo cria diversidade. E a diversidade é a maneira pela qual os pais se previnem contra um ambiente imprevisivelmente mutável (Wilson, 1978, p. 122).

Nas espécies que apresentam um comportamento social complexo - incluindo a espécie humana, mas não exclusivamente -, a sexualidade desenvolveu uma função adaptativa suplementar, uma "exaptação", para empregar o termo de Gould e Vrba (1982). O termo designa o fato de que um traço moldado pela seleção natural para certa função (uma adaptação) seja cooptado para um novo uso ou que um traço originalmente não adaptativo adquira um uso ao longo da evolução da espécie. O próprio subtítulo do trabalho de Gould e Vrba ("um termo que falta na ciência da forma") mostra que ele foi originalmente aplicado a características morfológicas (as penas, por exemplo, que cumpriam originalmente apenas uma função termorreguladora em certas espécies de dinossauros, adquiriram uma função ostentatória na seleção sexual e, finalmente, foram cooptadas para o voo dos pássaros). Mas o termo pode ser aplicado também a traços comportamentais. Um exemplo relevante para o comportamento sexual humano é o hábito dos primatas de catarem-se mutuamente os piolhos, que foi cooptado de sua função higiênica e alimentar original para tornar-se um fator de coesão social, perpetuando-se ainda no apreço humano pelo cafuné. 
Assim, além de produzir diversidade genética, a sexualidade passa a criar e/ou reforçar os vínculos afetivos entre os indivíduos, constituindo-se em uma forte motivação para a interação social. Isso ocorreu de forma exemplar na evolução da sociabilidade e, sobretudo, da vida familiar humana, em que a formação de grupos familiares permanentes, monogâmicos ou moderadamente poligínicos, foi um elemento decisivo na constituição do tecido social mais amplo. $\mathrm{O}$ prazer associado às práticas sexuais cumpre uma função decisiva no estabelecimento e manutenção desses vínculos, a tal ponto que, no comportamento social humano, essas características se sobrepõem e ultrapassam largamente em importância as funções reprodutivas da sexualidade.

A característica mais expressiva do vínculo sexual, de significação preponderante para a organização sexual humana, é que ele transcende a atividade sexual. A diversificação genética, função última do sexo, é secundada pelo prazer físico do ato sexual e supera em importância o processo da reprodução. O vínculo sexual é também secundado pelo prazer e cumpre, por sua vez, outros papéis, alguns dos quais estão relacionados com a reprodução apenas remotamente. Essas múltiplas funções e complexas cadeias causais são a razão mais profunda pela qual a consciência sexual tanto permeia a existência humana (Wilson, 1978, p. 138).

Desde esse ponto de vista, haveria razões estritamente biológicas, mas diferentes da reprodução, para a virtual onipresença da sexualidade na vida humana, cuja descoberta e investigação tem sido uma das contribuições perenes da psicanálise. O ponto a ser ressaltado é que a importância e a originalidade da contribuição psicanalítica não são em nada diminuídas ao se reconhecer que a sexualidade humana tem um fundamento biológico e instintivo. Inclusive no que diz respeito à importância da sexualidade no estabelecimento e consolidação das formas especificamente humanas de sociabilidade, não se pode esquecer a extensa análise desenvolvida por Freud (1998 [1921]), em que ele remeteu os fundamentos do laço social aos vínculos libidinais (sexuais, portanto) e identificatórios (derivados dos primeiros) estabelecidos entre os membros das associações humanas, que transparecem mais visivelmente nos fenômenos espontâneos de massa, mas que podem ser generalizados sem maiores problemas para instituições sociais fortemente organizadas, como as igrejas e os exércitos, e daí para o conjunto da sociedade. Essa análise aparece assim como uma confirmação da natureza e da função biológica da sexualidade, e não como sua refutação.

Até mesmo a significação que a biologia atribui ao prazer sexual como reforçador primário de vínculos permanentes entre os indivíduos converge com a centralidade que a psicanálise, desde Freud, atribui ao princípio de prazer como um dos fatores reguladores decisivos da ação humana; a restrição que Freud coloca, a partir de 1920, à 
universalidade dessa regulação, com a introdução do conceito de compulsão à repetição, será tratada indiretamente na segunda parte do artigo, quando se discutirá a possibilidade de atribuir uma significação biológica aos instintos de morte (Todestriebe) freudianos. O comportamento sexual humano está essencialmente vinculado ao prazer, quer em suas formas diretas, quer em suas manifestações sublimadas, de tal maneira que se converte em uma dimensão essencial de seu comportamento social mais amplo.

Em diversos de seus aspectos, a sexualidade humana é uma função biologicamente hipertrófica, que impregna quase a totalidade de sua vida social, o que se manifesta tanto no plano comportamental (a constância do interesse e da receptividade sexual) quanto, inclusive, no plano morfológico, por exemplo, na saliência e nas dimensões relativamente exageradas do pênis humano quanto comparado com o dos primatas mais proximamente aparentados (cf. Diamond, 2006, [1993], cap. 5). A significação dessa característica chamativa do macho humano já foi objeto de muita discussão (cf. Hickman, 2013) e fornece mais uma ocasião para uma aproximação com a psicanálise. A questão da eficiência no processo de inseminação sequer se coloca, pois a mesma poderia ser realizada a contento por um órgão muito menor, como os casos documentados de mutilação acidental muito bem demonstram. Ela não parece estar relacionada à exibição para as fêmeas na seleção sexual (como a cauda do pavão e a plumagem da ave-do-paraíso), já que as pesquisas disponíveis mostram que o aspecto ou o tamanho do pênis desempenham um papel bastante secundário na atração sexual das mulheres pelos homens e, portanto, na escolha dos parceiros. Ao contrário, como o próprio folclore da vida sexual sugere, são os homens que manifestam um grande interesse pelo seu próprio pênis e pelos dos demais. Em termos evolutivos, as características do pênis humano parecem ter-se desenvolvido como uma forma de ostentação e intimidação dos machos entre si (como as galhadas dos cervos, por exemplo) e não para a atração das fêmeas (como a cauda do pavão). Toda a teorização psicanalítica em torno do falo teria assim, como objeto, a análise da significação psicológica desse traço anatômico distintivo da espécie humana, cuja própria justificação biológica depende muito mais de seus aspectos imaginários (ser visto, mostrado, admirado, temido etc.) do que da função real que ele possa desempenhar no acasalamento. Tal dimensão imaginária do órgão sexual masculino complementar-se-ia com uma série de dispositivos simbólicos, na medida em que o aparato cultural relacionado ao falo se desenvolvesse. Esse aparato não deixa, aliás, de refletir a assimetria social nas relações de poder entre homens e mulheres, que caracterizou mesmo as sociedades ocidentais até muito recentemente e ainda não se encontra inteiramente ultrapassada. Seja como for, a teorização psicanalítica sobre o falo abordaria as consequências psíquicas de todo esse processo evolutivo, simultaneamente biológico e cultural. 
Embora evidentemente não se incline por uma desnaturalização do instinto sexual, a sociobiologia não fica atrás da psicanálise em reconhecer a centralidade do prazer e a importância da sexualidade no estabelecimento dos vínculos sociais.

Os seres humanos são connoisseurs do prazer sexual. Deleitam-se com a inspeção casual dos parceiros em potencial, com fantasias, com a poesia e com a canção, e com todas as nuanças deliciosas do flerte que conduzem às carícias amorosas e ao coito. Tudo isso tem pouco ou nada a ver com a reprodução; mas tem muito a ver com a união. Se a inseminação fosse a única função biológica do sexo, poderia ser realizada muito mais economicamente em alguns segundos de cobertura e penetração. Com efeito, os mamíferos menos sociais acasalam-se com uma cerimônia muito pouco mais elaborada do que isso. As espécies que desenvolveram vínculos duradouros também são, de modo geral, aquelas que dependem de elaborados rituais de corte. É coerente com essa tendência o fato de a maioria dos prazeres sexuais da espécie humana constituir reforçadores primários que facilitam a união. O amor e o sexo sem dúvida caminham juntos (Wilson, 1978, p. 141, grifos meus).

Não parece haver, assim, um obstáculo incontornável que impeça a abordagem das propriedades que a psicanálise atribui à sexualidade humana desde um ponto de vista biológico e, portanto, de conceber o Trieb sexual de que falou Freud como um operador conceitual para teorizar sobre as formas específicas de manifestação do instinto sexual na espécie humana.

\section{Conclusões PReliminares}

Ao que tudo indica, portanto, até este ponto, os argumentos comumente opostos a uma interpretação do "Trieb" freudiano como instinto, no sentido biológico do termo, não parecem ser tão conclusivos quanto comumente se pretendem. Em primeiro lugar, a opção pelo termo "Trieb", por si só, diante da designação alternativa "Instinkt", não conota nenhuma inclinação antinaturalista, pelo menos não necessariamente. $\mathrm{O}$ termo "Trieb" é de uso corrente na literatura biológica de língua alemã e, baseados nas afirmações de Lorenz (cf. 1975 [1937]), seu uso era ainda mais corrente antes dos anos 1930, quando a disseminação da psicanálise e do behaviorismo passou a recomendar a outra opção, a bem da clareza. Embora o termo possa ter, evidentemente, outras significações, ele pode também, perfeitamente, designar aquilo que as teorias biológicas consideram como instinto. De resto, tudo indica que a preferência de Freud se deva a 
razões predominantemente estilísticas, já que ele tende a preferir os termos de origem germânica aos termos de origem greco-latina, na composição de seu vocabulário ("Vorstellung" em vez de "Idee", por exemplo).

Em segundo lugar, a crítica de Freud da redução da sexualidade à função reprodutiva tampouco implica necessariamente um movimento teórico de afastamento da significação biológica do "Trieb" como instinto sexual. Como se constatou, a própria biologia evolucionária afirma essa separação em termos bastante inequívocos. Foi sugerido aqui - e desenvolvido em outro lugar (cf. Simanke, 2013) - que a crítica de Freud se endereça mais precisamente ao uso normativo da referência à reprodução como padrão para uma regulação médica do comportamento sexual, e não tanto à ideia de que a sexualidade possua uma inequívoca base biológica. Essa base inclui um impulso para o acasalamento entre indivíduos de sexos opostos para o cumprimento de uma finalidade reprodutiva, mas não se restringe ao mesmo, como a biologia também reconhece e como a psicanálise e, antes dela, a medicina fartamente demonstraram.

Embora os exemplos utilizados para ilustrar o argumento desenvolvido aqui tenham provido, sobretudo, da biologia evolucionária de orientação darwinista ou neodarwinista, isso não quer dizer que a biologia subjacente às elaborações freudianas seja necessariamente desse tipo, ou epistemologicamente compatível com ele de forma integral. Essa preferência decorreu, em parte, da circunstância de que os exemplos mais característicos de formulações próximas ou reminiscentes das posições freudianas que usualmente se consideram como antibiológicas puderam ser aí encontrados. É claro que isso pode sugerir uma filiação ou um comprometimento mais sólido de Freud com esse tipo de orientação biológica, para o que, de resto, existem outras evidências (cf. Ritvo, 1990). Isso, no entanto, não implica que esse comprometimento seja exclusivo. Freud recorre à biologia na medida das necessidades internas de sua teoria, e não por uma adesão incondicional a essa ou aquela doutrina. Podem-se recolher evidências de outras influências, frequentemente discrepantes, sobre o pensamento biológico de Freud, como o lamarckismo, o evolucionismo spenceriano, a filosofia da natureza do romantismo, para mencionar apenas algumas. Porém, o objetivo deste trabalho não é avaliar o resultado desse conjunto de influências distintas e a consistência interna do pensamento biológico freudiano mas, antes, argumentar que esse pensamento existe e que é fundamental para a compreensão das teses psicanalíticas, na contramão de uma tendência mais ou menos dominante de interpretação no sentido contrário.

Resta examinar, então, a outra série de objeções comumente levantadas contra a interpretação do Trieb psicanalítico como instinto biológico, a saber, o tratamento que Freud dá ao problema da agressividade, sobretudo em suas manifestações mais extremas e destrutivas, e da autodestrutividade, ou seja, do direcionamento das tendências 
destrutivas, sejam elas quais forem, contra o próprio indivíduo. Como se sabe, esse tratamento se deu também no âmbito da teoria freudiana dos instintos, culminando na polêmica introdução, em 1920, do conceito de "instinto de morte" (Todestrieb). Mais talvez que a separação entre sexualidade e reprodução, esse conceito pareceu representar (ou requerer) um afastamento ainda mais decidido das concepções biológicas, adaptativas e evolucionárias dos instintos. É ao exame desse problema que se dedica a segunda parte deste trabalho, a ser publicada proximamente em Scientiae Studia.

Agradecimentos. O autor agradece o apoio do GNPq à pesquisa da qual resultou este trabalho, sob a forma de uma Bolsa de Produtividade em Pesquisa (Nível 1-D) concedida ao projeto Psicanálise, ciência e neurociência: Freud e a epistemologia das ciências da mente contemporâneas. Uma versão preliminar e resumida deste trabalho foi originalmente apresentada no IV Encontro Nacional de Pesquisadores em Filosofia e Psicanálise (Ouro Preto, 2010). Gostaria de agradecer a todos que participaram do debate, sobretudo a Ernani Chaves e Carlos Drawin, pela contribuição ao aperfeiçoamento dos argumentos então apresentados.

\author{
Richard Theisen Simanke \\ Departamento de Psicologia, \\ Instituto de Ciências Humanas, \\ Universidade Federal de Juiz de Fora, Brasil. \\ richardsimanke@uol.com.br \\ Freud's Trieb as instinct 1: \\ sexuality and reproduction
}

\begin{abstract}
Freud's concept of "drive" or "instinct" ("Trieb") has been widely acknowledged as one of the most fundamental concepts of psychoanalysis. However, its meaning is still a matter of controversy. It was originally defined by Freud in a biological or quasi-biological sense, but its reception in many different postFreudian traditions has often tended to reject this early epistemological affiliation. One sign of this theoretical reorientation has been to refuse the translation of "Trieb" as "instinct" and to favor instead the neologism "pulsion" ("drive"), which has French origins and became common in the psychoanalytic literature written in many neo-Latin languages, including Portuguese. The objective of this paper is to criticize this trend. For that, the main arguments usually presented against a biological view of Freud's "Trieb" are discussed, namely: (1) the terminological alternative between the German words "Trieb" and "Instinkt" and how these terms are employed by Freud; (2) Freud's critique of the reduction of human sexuality to the reproductive function; (3) the concept of "Todestrieb" ("death instinct" or "death drive"), formulated by Freud around 1920 and central in the last stage of his thought. It is argued that these formulations do not preclude a biological interpretation of the concept of "Trieb". Such interpretation, in turn, opens the way for dialogue between psychoanalysis and biology, a dialogue which was also emphatically and explicitly
\end{abstract}


supported by Freud. This first part of the paper is an introduction to this issue, and approaches the problem of the relationship between sexuality and reproduction in psychoanalysis and biology. A second part will be published in a forthcoming issue of Scientiae Studia; it will be dedicated to the problem of aggression and self-destructiveness in these two fields of knowledge.

KeYwords • Freud. Psychoanalysis. Metapsychology. Instinct. Drive. Biology. Death. Sexuality.

\section{REFERÊNGIAS BIBLIOGRÁFICAS}

Caropreso, F. Freud e a natureza do psíquico. São Paulo: Annablume/Fapesp, 2010 .

. Dor e desejo na teoria freudiana do aparelho psíquico e das neuroses. Aurora, 21, 29, p. 569-9o, $2010 \mathrm{~b}$.

Caropreso, F. \& Simanke, R. T. Life and death in Freudian metapsychology: a reappraisal of the second instinctual dualism. International Journal of Psychoanalysis, 89, p. 977-92, 2008.

Catton, W. R. \& Dunlap, R.E. Environmental sociology: a new paradigm. American Sociologist, 13, p. 419, $197^{8}$

Diamond, J. The third chimpanzee: the evolution and future of the human animal. New York: Harper, 2006 [1993].

Foley, R. Another unique species: patterns in human evolutionary ecology. New Jersey: Wiley, 1987.

Freud, S. Tres ensayos de teoría sexual. In: Straghey, J. \& Freud, A. (Ed.). Obras completas de Sigmund Freud. Traducción J. L. Etcheverry. Buenos Aires: Amorrortu, 1998 [1905]. v. 7, p. 109-222.

. La perturbación psicógena de la visión según el psicoanálisis. In: Strachey, J. \& Freud, A. (Ed.).

Obras completas de Sigmund Freud. Traducción J. L. Etcheverry. Buenos Aires: Amorrortu, 1998 [1910]. v. 11, p. $205^{-16}$.

. Puntualizaciones psicoanalíticas sobre un caso de paranoia (Dementia paranoides) descrito autobiográficamente. In: Strachey, J. \& Freud, A. (Ed.). Obras completas de Sigmund Freud. Traducción J. L. Etcheverry. Buenos Aires: Amorrortu, 1998. [1911]. v. 12, p. 11-76.

. Pulsiones y destinos de pulsión. In: Strachey, J. \& Freud, A. (Ed.). Obras completas de Sigmund Freud. Traducción J. L. Etcheverry. Buenos Aires: Amorrortu, 1998 [1915]. v. 14, p. 113-34.

. Más allá del principio de placer. In: Strachey, J. \& Freud, A. (Ed.). Obras completas de Sigmund

Freud. Traducción J. L. Etcheverry. Buenos Aires: Amorrortu, 1998 [1920]. v. 18, p. 1-62.

. Psicología de las masas y análisis del yo. In: Strachey, J. \& Freud, A. (Ed.). Obras completas de Sigmund

Freud. Traducción J. L. Etcheverry. Buenos Aires: Amorrortu, 1998 [1921]. v. 18, p. 63-136.

. El yo y el ello. In: Strachey, J. \& Freud, A. (Ed.). Obras completas de Sigmund Freud. Traducción J. L.

Etcheverry. Buenos Aires: Amorrortu, 1998 [1923]. v. 19, p. 1-59.

Inhibición, síntoma y angustia. In: Straghey, J. \& Freud, A. (Ed.). Obras completas de Sigmund Freud.

Traducción J. L. Etcheverry. Buenos Aires: Amorrortu, 1998 [1926].v. 20, p. 83-161.

. Nuevas conferencias de introducción al psicoanálisis, $32^{\mathrm{a}}$ conferencia: Angustia y vida pulsional.

In: Strachey, J. \& Freud, A. (Ed.). Obras completas de Sigmund Freud. Traducción J. L. Etcheverry.

Buenos Aires: Amorrortu, 1998 [1933].v. 22, p. 75-103.

. Moisés y la religión monoteísta. In: Strachey, J. \& Freud, A. (Ed.). Obras completas de Sigmund

Freud. Traducción J. L. Etcheverry. Buenos Aires: Amorrortu, 1998 [1938]. v. 23, p. 1-132.

. As pulsões e seus destinos. Belo Horizonte: Autêntica, 2013.

Gould, S. J. Ontogeny and phylogeny. Cambridge: Belknap/Harvard University Press, 1977.

Gould, S. J. \& VRBA, E. S. Exaptation: a missing term in the science of form. Paleobiology, 8, 1, p. 4-15, 1982 . 
Hanns, L. A. Dicionário comentado do alemão de Freud. Rio de Janeiro: Imago, 1996.

Hickman, T. Um rabisco de Deus: o pênis, da criação aos dias de hoje. São Paulo: Bússola, 2013.

Hoffmann, G. Des cerveaux et des hommes: nouvelles recherches psychanalytiques. Paris: Ères, 2007.

O antinaturalismo da pulsão freudiana. In: Oliveira, C. (Org.). Filosofia, psicanálise e sociedade.

Rio de Janeiro: Azougue Editorial, 2010. p. 67-82.

Lacan, J. Le séminaire, Livre VII: l'éthique de la psychanalyse. Paris: Seuil, 1986 [1959-1960]. . Le séminaire, Livre XX: encore. Paris: Seuil, 1999 [1972-1973].

Laplanche, J. Vie et mort en psychanalyse. Paris: Flammarion, 1970.

Laplanche, J.; Сotet, P. \& Bourguignon, A. Traduire Freud. Paris: PUF, 1989.

Laplanche, J. \& Pontalis, J. B. Vocabulário da psicanálise. São Paulo: Martins Fontes, 1995.

LoREnz, K. Sobre a formação do conceito de instinto. In: Três ensaios sobre o comportamento animale humano: as lições da evolução da teoria do comportamento. Lisboa: Arcádia, 1975 [1937].

Mills, J. Clarifications on Trieb: Freud's theory of motivation reinstated. Psychoanalytic Psychology, 21, 4, p. $67^{3-7}, 2004$.

Oliverra, C. (Org.) Filosofia, psicanálise e sociedade. Rio de Janeiro: Azougue Editorial, 2010.

Ritvo, L. Darwin's influence on Freud: a tale of two sciences. New Haven: Yale University Press, 1990.

Savian Filho, J. Para ler Freud: entrevista com Paulo César Souza, tradutor para o português das obras completas do pai da psicanálise. Cult, 147, p. 57-9, 2010.

Schaeffer, J. M. La fin de l'exception humaine. Paris: Gallimard, 2007.

Simanke, R. T. A universalização da falta: o risco normativo da psicanálise lacaniana. Winnicott E-prints, 7,1, p. 49-79, 2013.

Strachey, J. \& Freud, A. (Ed.). Obras completas de Sigmund Freud. Traducción J. L. Etcheverry. Buenos Aires: Amorrortu, 1998. 24, v.

Tavares, P. H. Sobre a tradução do vocábulo Trieb. In: Freud, S. As pulsões e seus destinos. Belo Horizonte: Autêntica, 2013.p. $7^{3-90 .}$

Wilson, E. O. On human nature. Cambridge/London: Harvard University Press, $197^{8}$. 